\title{
A Qualitative Mineral Analysis of the Coarse Fraction of an Alonso Soil
}

\author{
Héctor M. Lugo, Juan Colom, and Rafael Pietri
}

\section{INTRODUCTION}

In terms of area, Alonso clay represents only about 1 percent of the crop land of Puerto Rico; yet it is an extensive, deep, upland soil which is very desirable for the production of coffee and minor crops. Details concerning the origin and classification of Alonso are available elsewhere $(5)^{2}$ and additional data is in press SCS, USDA.

Previous mineralogical analyses of Alonso $(s, 4)$ on fractions other than the clay have been reported to contain quartz in the very fine sand and silt fractions. No specific reference is made, however, to the quartz content in the coarser sand fractions. During the course of a general mineralogical analysis performed on soil samples obtained from a typical Alonso profile by a Soil Conservation Service survey party, it was observed that the quartz content increased from the clay up to the fine sand fractions and then decreased toward the coarse sand. In previous work by Jeffries, Bonnet and Abruña $(3,4)$, no analysis was made for the presence of iron-bearing minerals. These are considered to be important mineralogical characteristics of ultisols and may be useful in the classification and interpretation of their properties.

The present work is intended as a contribution toward the further characterization of Alonso clay in terms of its mineral constituents.

\section{MATERIALS AND METHODS}

A typical Alonso clay site, ${ }^{8}$ located by a USDA Soil Conservation Service survey party near Segunda Unidad School at Anones, Las Marias, Puerto Rico, was trenched to a depth of 8 feet. Soil samples were collected from this pit at 4-inch depth intervals. The samples were air-dried and separated into their textural components by following the procedure outlined by Jackson $(2,1)$, except for the removal of iron which was omitted. The sand fraction was sieved in two separates: $2000-105 \mu$ and 105-44 $\mu$, equivalent diameters.

1 Instructor and Research Assistant, College of Agriculture and Mechanical Arts and Agricultural Experiment Station, and Professors, College of Agricultural Experiment Station, and Professors, College of Agriculture and Mechanical Arts, Mayagulez Campus, University of Puerto Rico, Mayagüez, P.R.

2 Italic numbers in parentheses refer to Literature Cited, p. 69.

The soil samples used in the present study were provided by Mr. Luis H. Rivera, Staff Soil Scientist, and Mr. Joaquin Torres Mas, Soil Scientist, Soil Conservation Service, USDA. 
All fractions, except the 5-2 $\mu$, were then washed with distilled water, dried at $105^{\circ} \mathrm{C}$., ground to pass 100 mesh and finally mounted on aluminum sample holders for $X$-ray powder examination. The $5-2 \mu$ fractions were not allowed to dry before mounting on glass slides for $\mathrm{X}$-ray diffraction. Cobalt $\mathrm{K} \alpha$ radiation with $1^{\circ}-0.006$ inch $-1^{\circ}$ slit arrangement, scanning at $1^{\circ}, 2 \theta$ per minute from a Norelco unit, was used.

The X-ray diffraction angles were analysed by comparing their corresponding d-spacings with those of the X-ray powder data file, American Society for Testing Materials. An IBM ${ }^{4}$ program was established to identify the minerals present and the IBM selections were always re-examined by visual inspections of the $X$-ray patterns.

TABLs 1.-Mechanical analyses of profile of Alonso soil

\begin{tabular}{|c|c|c|c|c|c|c|c|c|c|}
\hline \multirow{3}{*}{$\begin{array}{c}\text { Particle } \\
\text { sitze } \beta\end{array}$} & \multicolumn{8}{|c|}{ Profile depth (inches) } & \\
\hline & o-s & $6-10$ & $10-14$ & $17-21$ & $21-25$ & $30-34$ & $34-38$ & $43-47$ & \\
\hline & \multicolumn{8}{|c|}{ Percent } & \\
\hline \multirow{3}{*}{$\begin{array}{c}2000-105 \\
105-44\end{array}$} & 2.3 & 2.1 & 3.1 & 4.7 & 2.6 & 6.2 & 5.8 & 5.4 & \multirow{7}{*}{ Total percent sand } \\
\hline & 2.5 & 3.9 & 5.6 & 6.3 & 4.0 & 8.7 & 9.1 & 8.2 & \\
\hline & 4.8 & 6.0 & 8.7 & 11.0 & 6.6 & 14.9 & 14.9 & 13.6 & \\
\hline $44-20$ & 7.6 & 7.4 & 10.0 & 9.8 & 5.7 & 9.1 & 9.3 & 8.9 & \\
\hline $20-5$ & 25.3 & 25.4 & 21.8 & 21.5 & 19.1 & 18.7 & 19.2 & 13.3 & \\
\hline \multirow[t]{2}{*}{$5-2$} & 9.7 & 9.2 & 10.1 & 7.9 & 9.4 & 8.6 & 8.5 & 5.7 & \\
\hline & 42.6 & 42.0 & 41.9 & 39.2 & 34.2 & 36.4 & 37.0 & 27.9 & \\
\hline$<2$ & 52.6 & 52.0 & 49.4 & 49.8 & 59.2 & 48.7 & 48.1 & 58.4 & Total percent clay \\
\hline
\end{tabular}

\section{RESULTS AND DISCUSSION}

The size-frequency distribution of particles in the soil samples examined is shown in table 1. According to the International System of soil textureclassification, this is a silty clay for the first foot profile depth and a clay for lower depths. The total percent of sand appears to increase with profile depth while total silt was found to decrease. The percentage of clay follows a definite variation trend.

The predominant minerals detected consisted of quartz and iron minerals. Their relative distribution is shown in table 2. Besides quartz and iron minerals, feldspar and gamma alumina were also identified, but these only in traces. It was not possible, therefore, to assign the rather low intensity

- The authors are indebted to Prof. Victor D\&́vila, Director of the Computer Center, Mayagüez Campus, Univ. of P.R., for his valuable cooperation. 
feldspar peaks to any particular feldspar specie. There was no indication, however, of the presence of orthoclase. The X-ray diffraction patterns showed numerous peaks but these were not sufficiently prominent for IBM or visual identification, using the necessary prominence sequence required to employ the A.S.T.M. X-ray data file.

Quartz appears to be the predominant mineral. Its diffraction is more intensive in the intermediate separates; that is, around $44 \mu$ to $5 \mu$ fraction.

TABLE 2.-Mineral distribution of a typical Alonso profile

\begin{tabular}{|c|c|c|c|c|c|c|c|c|c|c|}
\hline \multirow{3}{*}{ Mineral } & \multirow{3}{*}{ 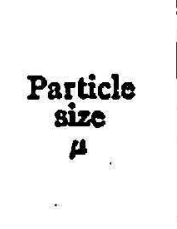 } & \multicolumn{8}{|c|}{ Profile depth (inches) } & \multirow{3}{*}{$\begin{array}{c}\text { Profile } \\
\text { average } \\
\text { counts } / \text { sec. }\end{array}$} \\
\hline & & $0-4$ & $6-10$ & $10-14$ & $17-21$ & $21-25$ & $30-34$ & 34-38 & $43-47$ & \\
\hline & & \multicolumn{8}{|c|}{ 'Counts per second of the most intensive peak } & \\
\hline \multirow[t]{5}{*}{ Quartz } & $2000-105$ & 82 & 73 & 66 & 78 & 65 & 60 & 78 & 70 & 72 \\
\hline & $105-44$ & 93 & 106 & 80 & 100 & 78 & 56 & 73 & 97 & 85 \\
\hline & $44-20$ & 124 & 91 & 101 & 102 & 93 & 85 & 97 & 121 & 102 \\
\hline & $20-5$ & 105 & 97 & 106 & 101 & 101 & 103 & 101 & 113 & 103 \\
\hline & $5-2$ & 35 & 39 & 37 & 19 & 44 & 40 & 62 & 30 & 38 \\
\hline \multirow{5}{*}{$\begin{array}{l}\text { Magnetite and } \\
\text { Maghemite }\end{array}$} & 2000-105 & 22 & 50 & 50 & 60 & 52 & 73 & 78 & 34 & 51 \\
\hline & $105-44$ & 40 & 60 & 49 & 40 & 37 & 42 & 26 & 16 & 39 \\
\hline & $44-20$ & 23 & 44 & 37 & 33 & 39 & 40 & 31 & 19 & 33 \\
\hline & $20-5$ & 24 & 33 & 26 & 34 & 31 & 36 & 35 & 38 & 32 \\
\hline & $5-2$ & 10 & 16 & 13 & 13 & 14 & 9 & - & 一 & 9 \\
\hline \multirow[t]{5}{*}{ Hematite } & 2000-105 & 18 & 32 & 32 & 26 & 32 & 42 & 28 & 28 & 30 \\
\hline & $105-44$ & 20 & 29 & 19 & 20 & 27 & 28 & 25 & 13 & 23 \\
\hline & $44-20$ & 35 & 38 & 27 & 26 & 28 & 32 & 35 & 28 & 31 \\
\hline & $20-5$ & 30 & 29 & 31 & 25 & 36 & 38 & 27 & 43 & 32 \\
\hline & $5-2$ & 19 & 16 & 17 & 14 & 18 & 11 & - & - & 12 \\
\hline
\end{tabular}

1 Counts per second obtained by measuring the height of the peak in a calibrated (counts per second) scale.

The average profile intensity (counts per second of the most prominent peak) increased with a decrease in particle size down to the 20-5 $\mu$ separate. This is considered to be a rather peculiar behavior. It would be expected that the resistant quartz specie be concentrated in the coarser sand fraction and should decrease with decreasing particle size. The foregoing behavior suggests that quartz dissolves from coarser fractions and then recrystallizes into smaller nuclei corresponding to the intermediate separates, or the pedogenic soil matrix initially laid down was a quartziferous, fine-grained material. The former concept is considered to be the least probable, because it does not explain the sudden decrease in quartz content associated 
with the fractions of smaller size analyzed, as well as in the clay $(3,4)$. On the other hand, the latter interpretation appears to conform more closely with the observed distribution of quartz in the different separates, accounting for the uniform distribution of quartz throughout the profile, and with the rather uniform textural and depth characteristic of Alonso.
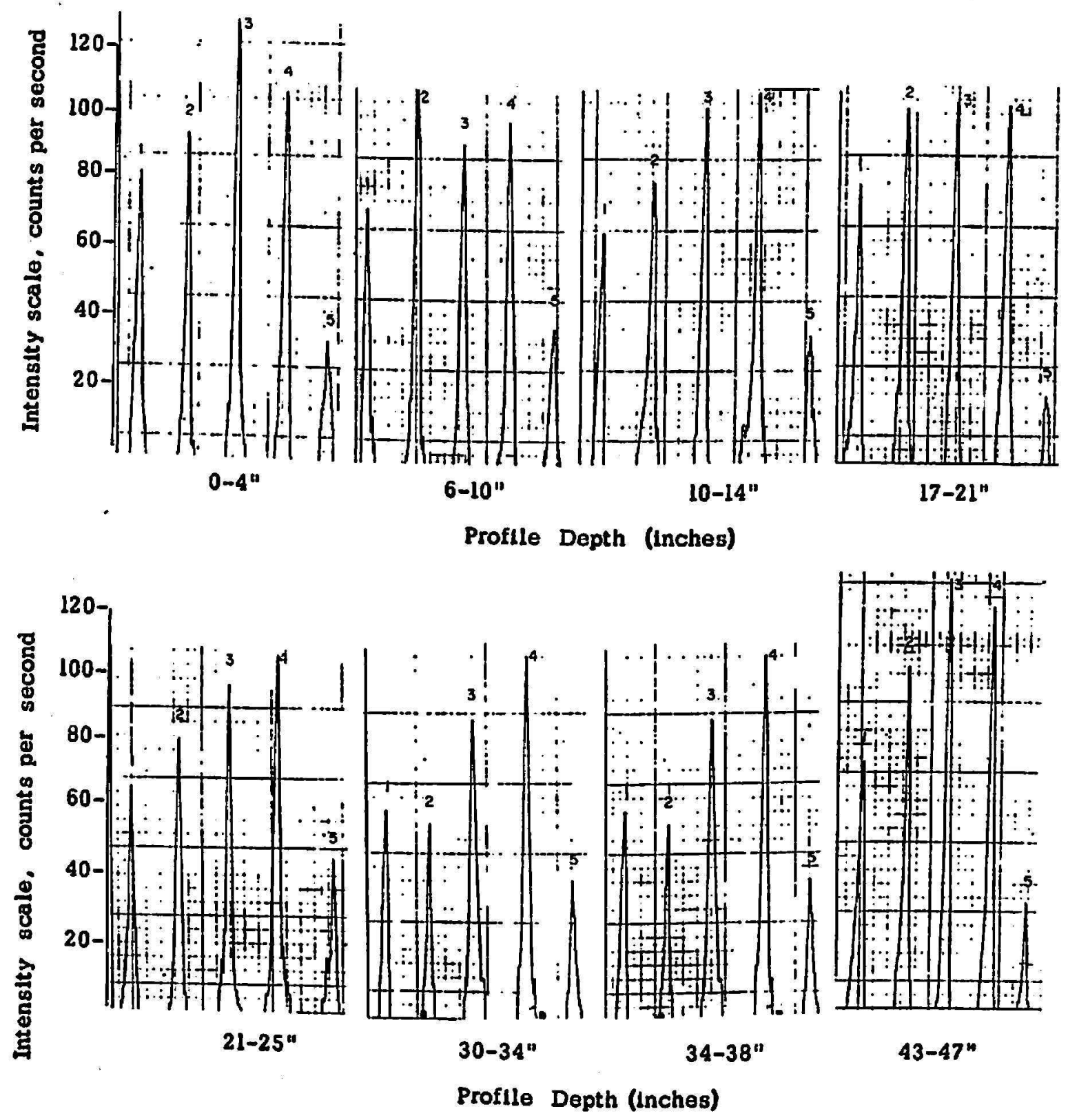

$$
\begin{aligned}
& \text { Particle size (microns) } \\
& 1 \text { - 2000-105 } \\
& 2 \text { - 105-44 } \\
& 3 \text { - 44-20 } \\
& 4 \text { - 20-5 } \\
& 5-5-2
\end{aligned}
$$
file.

Fig. 1. - Quartz distribution in the different soil fractions of a typical Alonso pro- 
Magnetite, maghemite and hematite were the iron minerals identified. Magnetite and maghemite were clearly present, but the reflection intensity of their most prominent peaks were so close that their separate contribution
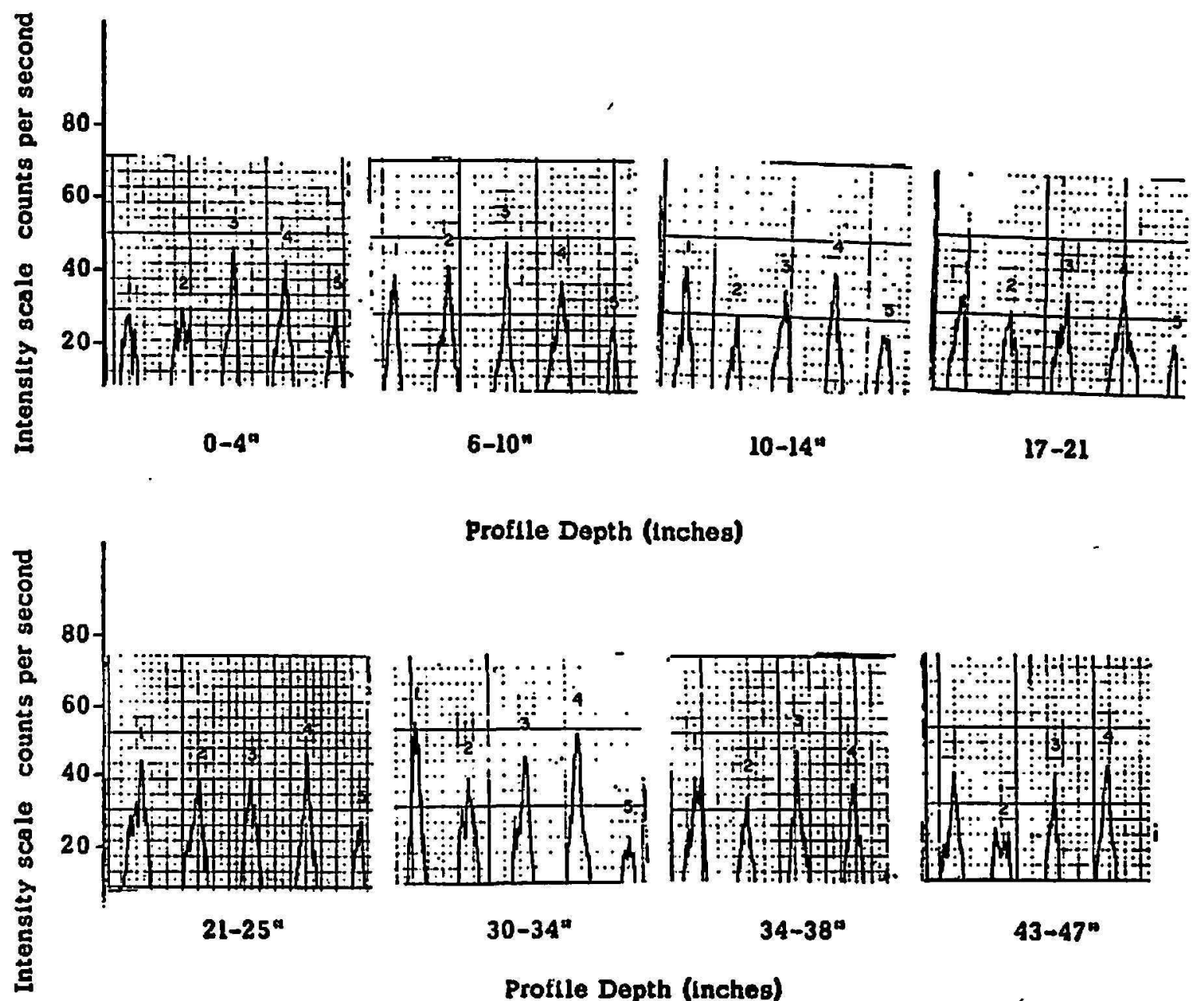

Profule Depth (Inches)
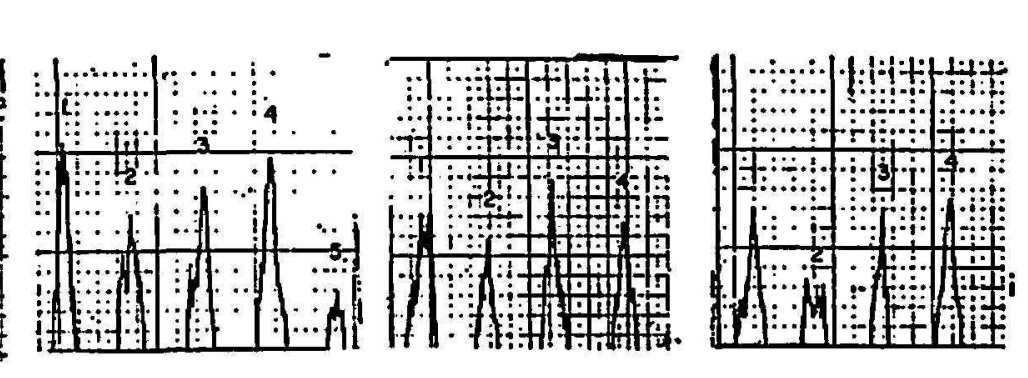

$30-34^{\text {म }}$

$34-38^{\circ}$

$43-47^{\circ}$

Profile Depth (inches)

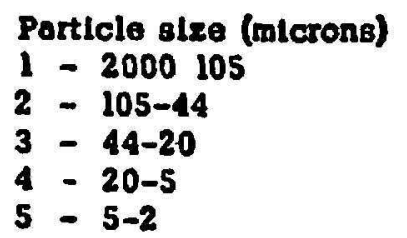

Fra. 2.-Hemantite distribution in the different soil fractions of a typical Alonso profile.

in counts per second were mutually reinforced, thus prohibiting separate intensity assignment. The iron minerals appear to follow a uniform, particlesize distribution pattern throughout the horizon, except for the very fine silt.

The most prominent peaks of the X-ray diffraction pattern for quartz and the iron minerals were isolated and reproduced in figures 1,2 and 3. The 
relative intensity sequence for the minerals discussed above is graphically illustrated. The effect of mutual reinforcement indicated above for magnetite and maghemite is evident in figure 3.

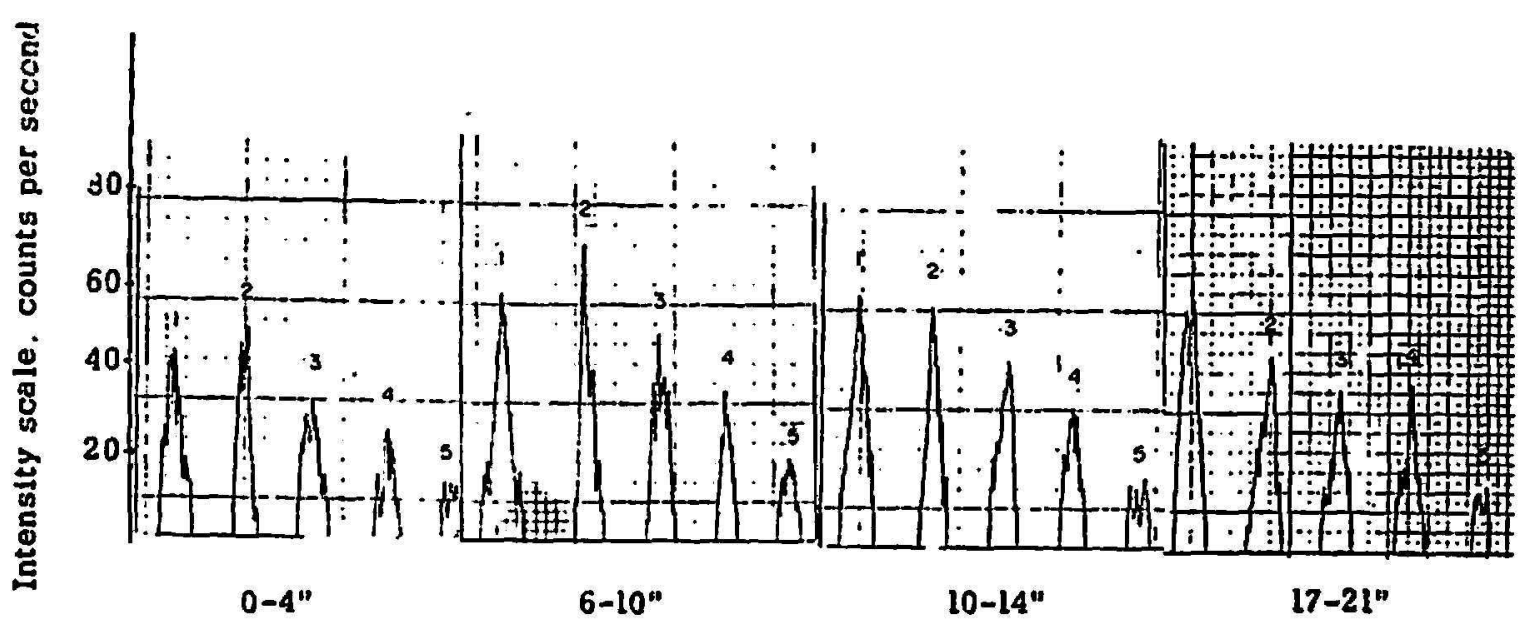

Profule Depth (inches)

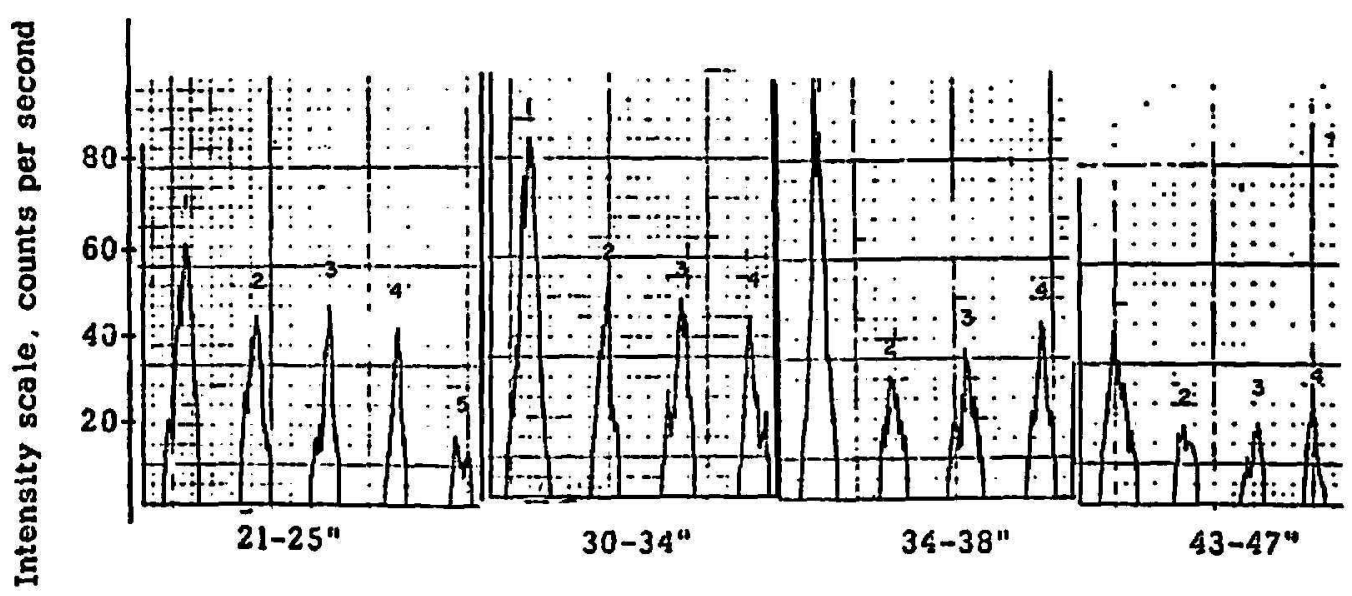

Protlle Depth (Inches)

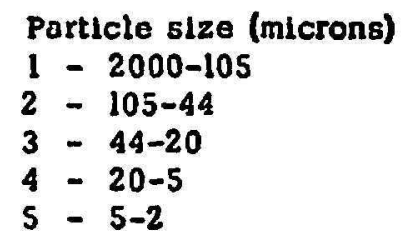

Fic. 3.-Magnetite and maghemite distribution in the different soil fractions of a typical Alonso profile.

The X-ray diffraction powder pattern of the rock formation andesite, normally associated with Alonso, and collected from an eroded nearby site, is presented in figure 4. The peaks corresponding to quartz, feldspar, calcite, 
hematite, magnetite and maghemite are prominently present. Although no special effort was made to distinguish between the various feldspars, it is evident, however that the orthoclase group is absent. The fact that calcite was prominently identified in the rock formation, while not reported in our soil analysis, is explained by the acid treatment given to the soil samples.

\section{SUMMARY}

Quartz, hematite, magnetite and maghemite were identified as the most prominent minerals present in the coarse fraction of a typical Alonso clay. Although plagioclase was an important constituent detected in the parent rock, only traces were found in the soil. There was no indication of the presence of orthoclase either in the rock or in the soil.

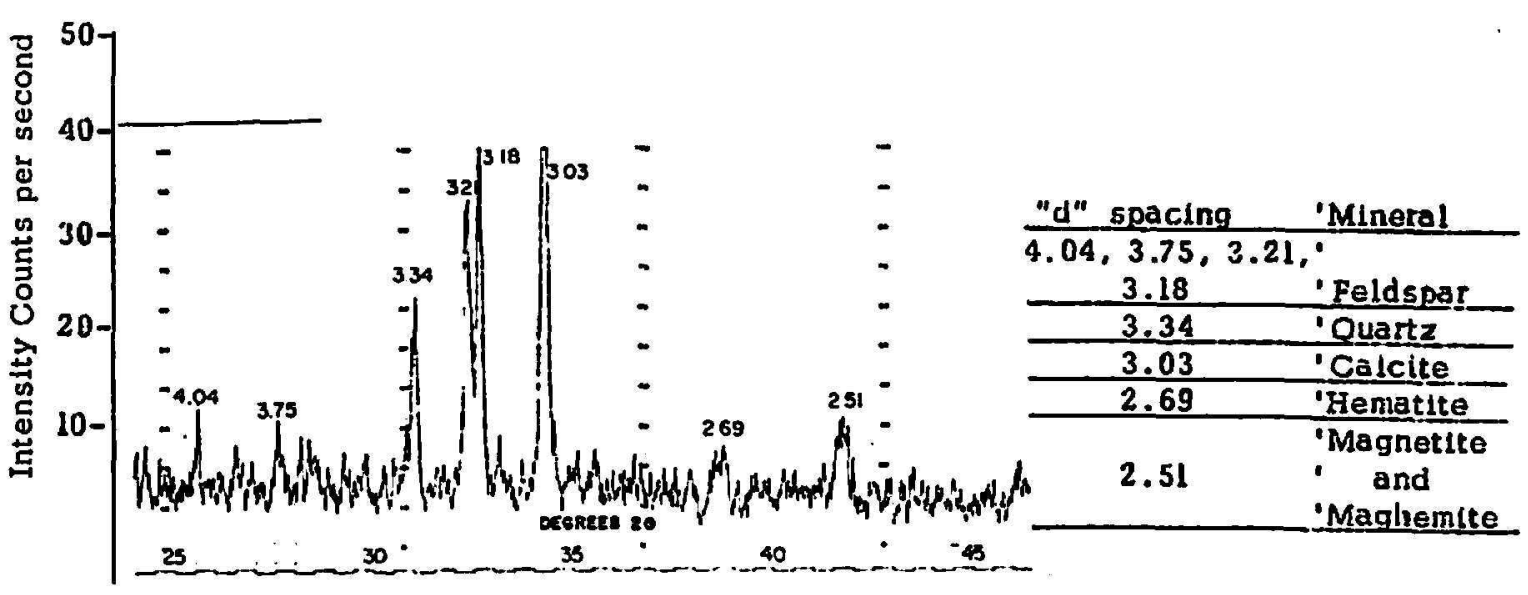

Fra. 4.-X-ray diffraction pattern of the rock formation associated with Alonso soil.

The iron minerals appear to follow a rather uniform distribution throughout the profile, while the most intensive peaks of quartz were more prominent in the silt rather than in the sand fractions. A possible explanation for the particle-size distribution of quartz could be the original textural composition of the pedogenic material as would be encountered in quartziferous volcanic ashes. Inasmuch as the percent of silt in the soil decreased with the profile depth, it is reasonable to expect a concomitant decrease in the relative quartz content of the soil.

\section{RESUMEN}

El cuarzo, la hematita, la magnetita y la maghemita fueron los minerales más prominentes que se identificaron de la fracción gruesa del suelo Alonso. A pesar de haberse encontrado que las plagioclasas son un componente importante de la roca que supuestamente dio origen a este tipo de suelo, solo aparecieron vestigios de este grupo de minerales en el suelo. No se encontraron indicios de la presencia de la ortoclasa en el suelo ni en la roca. 
Los minerales de hierro parecen seguir un patrón de distribución uniforme, mientras que el cuarzo aparece más concentrado en la fracción limo. Una posible explicación para la distribución peculiar del cuarzo parece encontrarse en la composición y disposición de las partículas en el material que dio origen al suelo, tal como se encontraría en las cenizas volcánicas cuarzosas. El hecho de que se registrara una reducción en el contenido de limo según se profundiza en el perfil, sugiere igualmente una relativa reducción en el contenido de cuarzo.

\section{LITERATURE CITED}

1. Jackson, M. L., Soil Chemical Analysis-Advanced Course, published by the author, Department of Soils, Univ. Wis., Madison, Wis., 1956.

2. Jackson, M. L., Whittig, L. D., and Pennington, R. P., Segregation procedure for the mineralogical analysis of soils, Soil Sci. Soc. Amer. Proc. (1949) 14: 77-81, 1950.

3. Jeffries, C. D., Bonnet, J. A., and Abrufia, F., The constituent minerals of some soils in Puerto Rico, J. Agr. Univ. P.R. s7 (2): 114-39, 1953.

4. Jeffries, C. D., Bonnet, J. A., and Abruña, F., Mineral characteristics of some soils of Puerto Rico, Soil Sci. Soc. Amer. Proc. 16 (3): 310-11, 1952.

5. Roberts, R. C., Soil Survey of Puerto Rico, USDA, Series 1936, No. 8, 1942. 